\title{
ANALISIS EVALUASI BIAYA DAN PENJADWALAN WAKTU PROYEK PENGOLAHAN LIMBAH PT. KI DENGAN PENDEKATAN PERT
}

\author{
M. Imron Mas'ud, Erik Wijayanti \\ Program Studi Teknik Industri, Universitas Yudharta Pasuruan \\ Email: imron.ie.uyp@gmail.com, erikwijayanti4@gmail.com
}

\begin{abstract}
Development industry now is significant so must be balance with waste treatment. The project waste treatment must be always control, so that the project activities are less effective and efficient, it will result in delays, decreasing the quality of work, and the swelling of implementation costs, one of which is a waste treatment project. This study aims to find out the evaluation of project scheduling and waste processing project cost by Project Evaluation Review Technique (PERT) approach either in manual calculation or POM software assistance. The results obtained that the waste processing project in PT. KI can be completed within 91 days and the critical path lies in the begin activity from $A-B-C-E-H-J-K$ until $L$ with the likelihood of completion of at least 85 days is $2.5 \%$, most likely to be completed 91 days is $95 \%$ and no later than 96 days is $2.5 \%$.
\end{abstract}

Keywords: PERT, Scheduling time, cost, waste treatment.

\section{PENDAHULUAN}

Perkembangan dunia industri saat ini sangat pesat guna meningkatkan daya saing tidak terkecuali pada penanganan limbah industri. Kegagalan atau keberhasilan proyek dibidang pengolahan limbah salah satunya disebabkan karena perencanaan kegiatan proyek belum terencana dengan baik dan benar, sehingga hal tersebut berdampak pada keterlambatan, menurunnya kualitas kinerja, bahkan berdampak pada membengkaknya biaya pelaksanaan (Hayun, 2005).

Berbagai efek dari keterlambatan penyelesai-an suatu proyek merupakan suatu kondisi yang tidak dharapkan oleh semua pihak yang disebabkan karena dapat merugikan kedua pihak, sehingga penggunaan waktu dan biaya harus seefektif dan seefisien mungkin (susilo, 2012), seperti pada pada proyek pembangunan instalasi pengelohan limbah.

Pembangunan pengolahan limbah dalam suatu industri sangat diperlukan perusahaan dan penanganannya harus baik dan benar, sehingga dibutuhkan ketelitian dalam perhitungan, baik dari segi waktu dan biaya untuk mencapai efisiensi (Badri, 1997). Berbagai variasi sumber daya sangat berbeda-beda tergantung pada proyek yang ditanganinya, hal ini menyebabakan terjadinya fluktuasi. Fluktuasi kebutuhan tersebut akan berdampak pada anggaran (Misrali, 2015) seperti pada proyek pembangunan instalasi pengelohan limbah PT. KI.

Untuk memenuhi kebutuhan konsumen yang semakin meningkat, PT. KI sebagai perusahaan besar di Indonesia yang bergerak dibidang makanan dan minuman, membangun plant baru di wilayah Pandaan Pasuruan untuk memproduksi minuman berkemasan botol (PET). Kapasitas produksinya mencapai 300 botol per menit, sehingga sehari mampu menghasilkan 432.000 botol atau sekitar 77.760 liter minuman. Oleh karena kapasitas produksinya besar, maka limbah cair yang dihasilkannya pun juga ikut besar. Untuk mengimbanginya, dibangunlah proyek pengolahan limbah tambahan berupa pemasangan mesin belt press dan untuk memperbaiki kualitas limbah yang akan dibuang ke lingkungan.

Durasi waktu penyelesaian proyek yang telah disepakati oleh kedua pihak yaitu selama tiga bulan atau 90 hari. Untuk menentukan waktu yang optimal diperlukan time schedule yang baik, yakni dengan analisis jaringan kerja metode PERT dan juga metode crashing project untuk mengantisipasi jika terjadi keterlambatan.

Suatu kegiatan proyek merupakan suatu kegiatan yang berlangsung secara sementara eering | Mechanical Engineering | Civil Engineering 
yang dibatasi oleh waktu, alokasi sumber daya serta dimaksudkan untuk menyelesaikan tugas dan sasaran yang telah ditentukan sebelumnya (Fadli, 2010).

Manajemen proyek merupakan pengaplikasi-an tools, keahlian, pengetahuan dan teknik lainnya ke dalam semua aktivitas proyek untuk menyelesaiakan suatu proyek (schwalbe, 2007).

Bagian paling penting suatu proyek yaitu perencanaan proyek, yang bertujuan untuk menentukan kapan sebuah proyek dapat dimulai pelaksanaannya, urutan pengerjaanya, alokasi biayanya, serta waktu yang dibutuhkannya. (Muhammad, 2015).

\section{Penjadwalan Proyek - Program Evaluation Review Technic (PERT)}

Tahun 1958, Booz Allen Hamilton menemukan metode penjadwalan suatu proyek yang diberi nama diagram PERT (Program Evaluation and Review Technique), teknik ini dipergunakan dalam perencanaan dan penjadwalan suatu proyek yang kompleks dan besar untuk mempermudah dalam proses disebabkan diagram PERT mampu mendeteksi ketidakpastian suatu proyek tanpa perlu mengetahui durasi pada setiap aktifitas.

Metode PERT mampu memberikan perkiraan waktu untuk menyelesaikan suatu kegiatan. metode PERT juga menjelaskan parameter lain untuk mengukur ketidakpastian secara kuantitatif seperti standar deviasi dan varians. Metode PERT menampung adanya unsur-unsur yang belum pasti, kemudian menganalisis kemungkinan-kemungkinan sejauh mana proyek menyimpang atau memenuhi.

Selai itu terdapat tiga angka estimasi yang bertujuan untuk memberikan rentang waktu yang paling lebar dalam melakukan sasaran dalam membuat estimasi kurun waktu kegiatan. Ketiga estimasi durasi tersebut adalah:

- Waktu optimis merupakan waktu yang tercepat untuk menyelesaikan suatu kegiatan jika segala sesuatunya berjalan dengan baik..

- Waktu paling mungkin, merupakan yang paling sering terjadi dibanding dengan yang lain.

- Waktu pesimis, merupakan waktu yang paling lama untuk menyelesaikan kegiatan.

Ketiga perkiraan waktu itu dirumuskan menjadi kurun waktu yang diharapkan (expected duration time) atau satu angka yang disebut (te). Rumusannya adalah (Yamit, 2003):

$$
t e=\frac{a+4 m+b}{6}
$$

Standar deviasi dan Varians Kegiatan

Estimasi kurun waktu kegiatan dalam metode PERT memakai rentang waktu dengan menandai derajat ketidakpastian yang berkaitan dengan proses estimasi kurun waktu kegiatan. Besarnya suatu ketidakpastian ini tergantung pada besarnya angka yang diperkirakan untuk a dan b. Parameter yang menjelaskan masalah ini dikenal sebagai deviasi standar dan varians. Berdasarkan ilmu statistik, angka deviasi standar adalah sebesar 1/6 dari rentang distribusi (b-a) atau bila ditulis dengan rumus adalah sebagai berikut :

Deviasi standar kegiatan:

$$
s=\frac{1}{6}(b-a)
$$

Varians kegiatan:

$$
V(t e)=s^{2}
$$

Dimana :

$S \quad=$ Deviasi standar kegiatan

$V(t e)=$ Varians kegiatan

Kemungkinan/ketidakpastian mencapai target dijadwal pada metode PERT dinyatakan dengan $z$ yaitu hubungan antara waktu yang diharapkan (EET) dengan target $T(d)$ dengan rumus sebagai berikut:

$$
\text { deviasi } z=\frac{T(d)-E E T}{s}
$$

Dimana :

$$
\begin{aligned}
z & =\text { Kemungkinan target yang hendak } \\
& \text { dicapai } \\
T(d)= & \text { Target waktu penyelesaian proyek } \\
E E T= & \text { Waktu paling awal peristiwa } \\
s \quad= & \text { Standar deviasi }
\end{aligned}
$$

Dengan menggunakan tabel distribusi normal akan dapat menentukan persentase proyek selesai pada target $\underline{T(d)}$

\section{Mempercepat Waktu Proyek - Crashing Method}

Dalam suatu proyek yang dikehendaki selesai dalam jangka waktu yang telah ditentukan, dapat dilakukan percepatan durasi kegiatan dengan konsekuensi akan terjadi peningkatan biaya. 
Untuk mempercepat waktu pengerjaan proyek maka diadakan percepatan durasi kegiatan pada jalur-jalur kritis, dengan syarat bahwa pengurangan waktu tidak akan menimbulkan jalur kritis baru. Salah satu cara untuk mempercepat waktu pelaksanaan proyek diantaranya dengan menambah waktu kerja dengan tenaga yang tersedia.

Penambahan jam kerja bisa dilakukan dengan penambahan 1 hari, 2 hari atau 3 hari penambahan sesuai dengan waktu penambahan yang diinginkan. Dengan adanya penambahan jam kerja.

Biaya total proyek merupakan penjumlahan biaya langsung dengan biaya tidak langsung. Biaya total proyek sangat tergantung terhadap waktu penyelesaian proyek, semakin lama proyek selesai makan biaya yang dikeluarkan akan semakin besar. Hubungan antara biaya dengan waktu dapat dilihat pada gambar 1. Titik A menunjukkan titik normal, sedangkan titik B adalah titik dipersingkat. Garis yang menghubungkan antara titik $\mathrm{A}$ dan titik $\mathrm{B}$ disebut kurva waktu-biaya

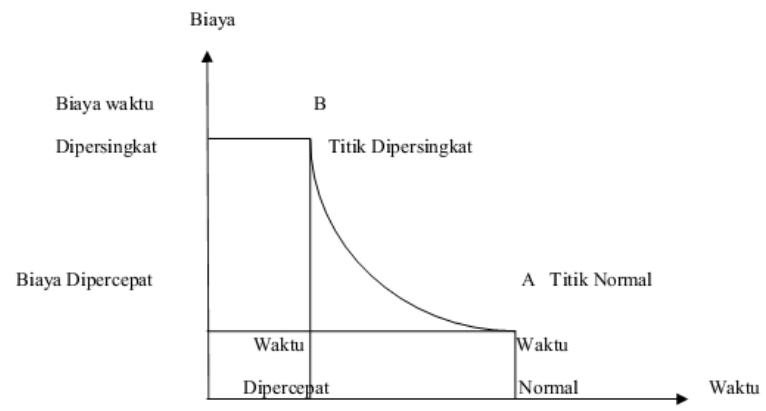

Gambar 1. Hubungan waktu - biaya normal dan dipersingkat untuk suatu proyek.

Untuk menghitung cost slope atau biaya percepatan per periode waktu pennyelesaian kegiatan digunakan persaman sebagai berikut :

$$
\text { cost slope }=\frac{\text { biaya cepat }- \text { biaya normal }}{\text { waktu normal }- \text { waktu cepat }}
$$
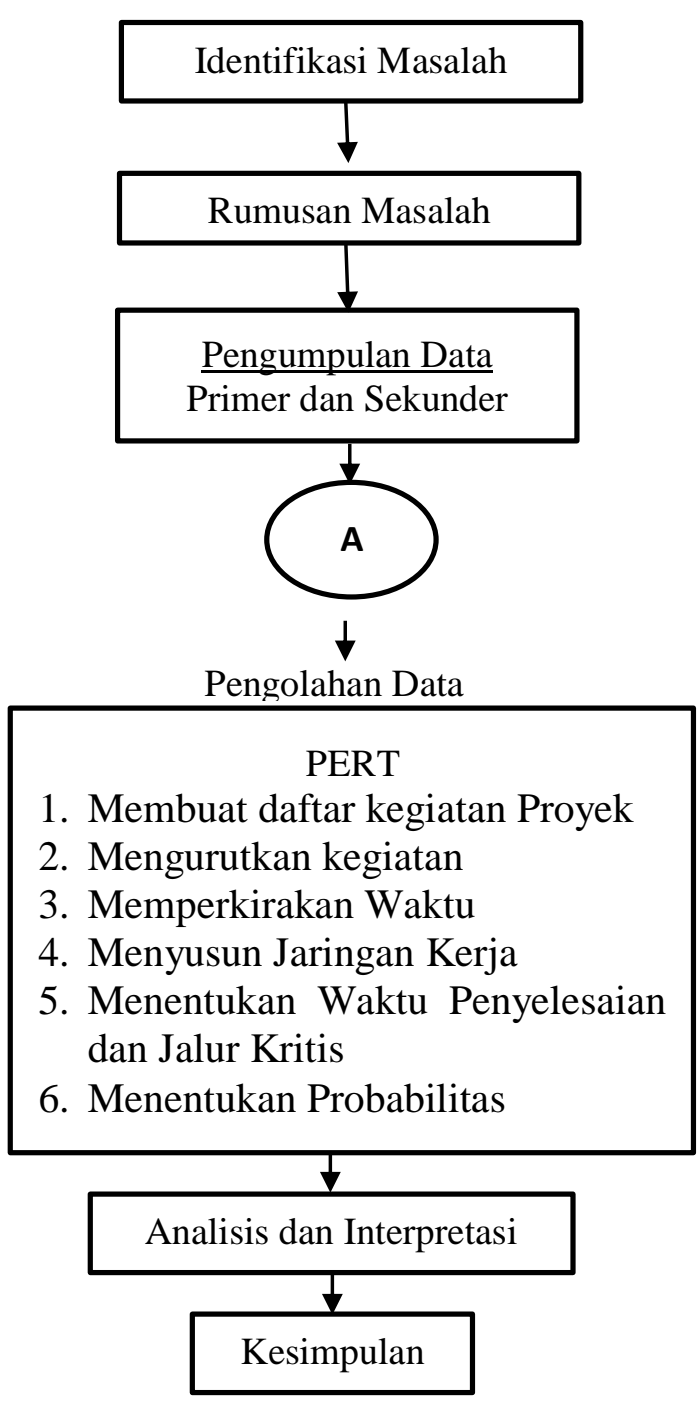

Gambar 1: Diagram Alir Penelitian

\section{HASIL DAN PEMBAHASAN}

Fokus penelitian pada proyek pengolahan limbah PT. KI Plant Pandaan pada proyek pemasangan mesin belt press. Berdasarkan hasil data lapangan diketahui bahwa durasi waktu pengerjaan proyek membutuhkan waktu 90 hari atau 3 bulan dengan total anggaran yang dibutuhkan sebesar Rp. 750.500.000,-. Bila proyek diperkirakan/prediksi akan mengalami keterlambatan, maka disusunlah suatu rencana percepatan proyek dengan cara penambahan 1 hari dan 2 hari waktu kerja.

\section{Jaringan Kerja (Manual)}

Penjadwalan proyek diawali.dengan mengesti-masikan waktu penyelesaian setiap item kegiatan proyek kedalam 3 jenis estimasi/prakiraan waktu yaitu waktu optimis $(a)$, waktu pesimis $(b)$, dan waktu yang paling

\section{METODE PENELITIAN}


mungkin $(m)$. Hasil analisa diketahui bahwa keseluruhan waktu seperti berikut:

Tabel 1. Estimasi waktu

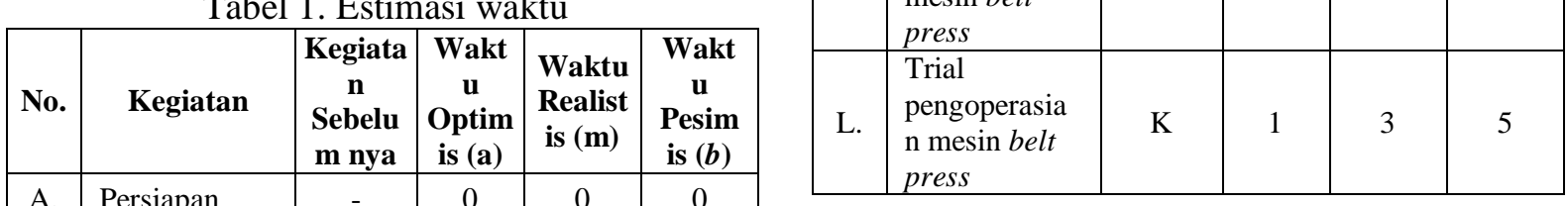

Kemudian mencari nilai te yang didapat sebagai berikut:

Tabel 2. Nilai waktu yang diharapkan $(t e)$

\begin{tabular}{|c|c|c|c|c|c|}
\hline A. & Persiapan & - & 0 & 0 & 0 \\
\hline B. & $\begin{array}{l}\text { Pondasi } \\
\text { bangunan }\end{array}$ & A & 12 & 14 & 17 \\
\hline C. & $\begin{array}{l}\text { Pembuatan } \\
\text { kerangka } \\
\text { konstruksi }\end{array}$ & B & 13 & 17 & 20 \\
\hline D. & $\begin{array}{l}\text { Pemasangan } \\
\text { atap }\end{array}$ & B & 12 & 15 & 18 \\
\hline E. & $\begin{array}{l}\text { Perakitan } \\
\text { mesin belt } \\
\text { press }\end{array}$ & $\mathrm{C}$ & 28 & 30 & 35 \\
\hline F. & $\begin{array}{l}\text { Pelevelan } \\
\text { media mesin } \\
\text { belt press }\end{array}$ & $\mathrm{C}$ & 2 & 4 & 6 \\
\hline G. & $\begin{array}{l}\text { Instalasi } \\
\text { penerangan }\end{array}$ & $\mathrm{D}$ & 1 & 2 & 3 \\
\hline H. & $\begin{array}{l}\text { Pemasangan } \\
\text { pompa dan } \\
\text { kompressor }\end{array}$ & $\mathrm{E}, \mathrm{F}$ & 5 & 9 & 13 \\
\hline I. & $\begin{array}{l}\text { Pemasangan } \\
\text { bak } \\
\text { penampung } \\
\text { sludge }\end{array}$ & $\mathrm{F}, \mathrm{G}$ & 4 & 7 & 8 \\
\hline J. & $\begin{array}{l}\text { Perakitan } \\
\text { kontrol panel } \\
\text { mesin belt }\end{array}$ & $\mathrm{H}, \mathrm{I}$ & 8 & 12 & 15 \\
\hline
\end{tabular}

\begin{tabular}{|c|l|c|c|c|c|} 
& press & & & & \\
\hline K. & $\begin{array}{l}\text { Pemasangan } \\
\text { kontrol panel } \\
\text { mesin belt } \\
\text { press }\end{array}$ & $\mathrm{J}$ & 3 & 5 & 7 \\
\hline L. & $\begin{array}{l}\text { Trial } \\
\text { pengoperasia } \\
\text { n mesin belt } \\
\text { press }\end{array}$ & $\mathrm{K}$ & 1 & 3 & 5 \\
\hline
\end{tabular}

\begin{tabular}{|c|c|c|} 
No. & Kegiatan & te (hari) \\
\hline
\end{tabular}

\begin{tabular}{|c|lc|}
\hline A. & Persiapan & 0 \\
\hline B. & Pondasi bangunan & 14.17 \\
\hline C. & Pembuatan kerangka konstruksi & 16.83 \\
\hline D. & Pemasangan atap & 15.00 \\
\hline E. & Perakitan mesin belt press & 30.50 \\
\hline F. & Pelevelan media mesin belt press & 4.00 \\
\hline G. & Instalasi penerangan & 2.00 \\
\hline H. & Pemasangan pompa dan kompressor & 9.00 \\
\hline I. & Pemasangan bak penampung sludge & 6.67 \\
\hline J. & $\begin{array}{l}\text { Perakitan kontrol panel mesin belt } \\
\text { press }\end{array}$ & 11.83 \\
\hline K. & $\begin{array}{l}\text { Pemasangan kontrol panel mesin belt } \\
\text { press }\end{array}$ & 5.00 \\
\hline L. & Trial pengoperasian mesin belt press & 3.00 \\
\hline
\end{tabular}

Dengan menggunakan nilai te (durasi waktu yang diinginkan/harapkan) sehingga diagram jaringan kerja proyeknya sebagai berikut:

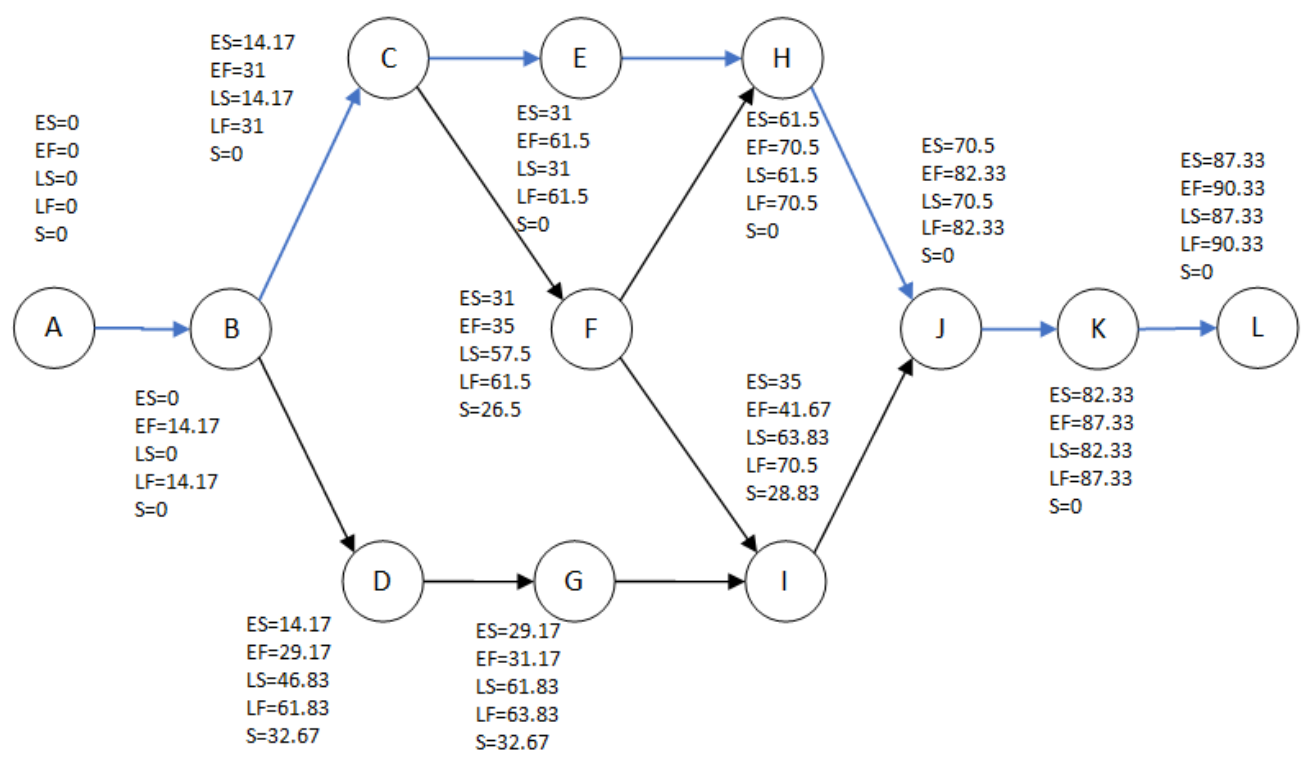

Gambar 2: Diagram Jaringan kerja proyek pengolahan limbah

Hasil analisa diketahui bahwa penyelesaian diagram jaringan kerja dimulai $\boldsymbol{A}-\boldsymbol{B}-\boldsymbol{C}-\boldsymbol{E}-\boldsymbol{H}-\boldsymbol{J}-\boldsymbol{K}$ proyek ini membutuhkan waktu selama 90.33 dan berakhir pada $\mathbf{- L}$.

hari atau 91 hari, jalur kritis (slack =0) serta

Computer Science | Industrial Engineering | Mechanical Engineering | Civil Engineering 
Berdasarkan hasil lintasan kritis yang telah didapat kemudian mencari nilai deviasi standard (s) berdasarkan persamaan (3.2) dan varians (V(te)) berdasarkan persamaan (3.3) pada proyek secara keseluruhan.

Tabel 3: Standar deviasi dan varians kegiatan

\begin{tabular}{|c|l|c|c|c|}
\hline No. & \multicolumn{1}{|c|}{ Kegiatan } & $T e$ & $\mathrm{~S}$ & $V(t e)$ \\
\hline A. & Persiapan & 0 & 0 & 0 \\
\hline B. & Pondasi bangunan & 14.17 & 0.83 & 0.69 \\
\hline C. & Pembuatan kerangka konstruksi & 16.83 & 1.17 & 1.36 \\
\hline E. & Perakitan mesin belt press & 30.50 & 1.17 & 1.36 \\
\hline H. & Pemasangan pompa dan kompressor & 9.00 & 1.33 & 1.78 \\
\hline J. & $\begin{array}{l}\text { Perakitan kontrol panel mesin belt } \\
\text { press }\end{array}$ & 11.83 & 1.17 & 1.36 \\
\hline K. & $\begin{array}{l}\text { Pemasangan kontrol panel mesin belt } \\
\text { press }\end{array}$ & 5.00 & 0.67 & 0.44 \\
\hline L. & Trial pengoperasian mesin belt press & 3.00 & 0.67 & 0.44 \\
\hline$\sum V(t e)$ & \multicolumn{3}{|c|}{7.44} \\
\hline S & \multicolumn{3}{|l|}{} \\
\hline
\end{tabular}

Berdasarkan hasil dari tabel diketahui bahwa total nilai varians $\left(\sum V(t e)\right)=7.44$ dan deviasi standar $(s)=2.73$. Kemungkinan / ketidakpastian pekerjaan selesai sesuai dengan deadline dinyatakan dengan nilai z seperti pada persamaan (3.4) :

$$
\begin{gathered}
\text { deviasi } z=\frac{T(d)-E E T}{S} \\
\text { deviasi } z=\frac{85-90.33334}{2.728451} \\
\text { deviasi } z=-1.95
\end{gathered}
$$

Hasil berdasarkan tabel distribusi normal, nilai $\mathrm{z}=-1.95$ diperoleh hasil 0.025 . Artinya sangat dimungkinkan proyek tersebut akan selesai dalam waktu target 85 hari sebesar $2.5 \%$.

\section{Jaringan Kerja (Software)}

Langkah-langkah analisis jaringan kerja dengan bantuan software POM-QM adalah sebagai berikut:

a. Pada module PERT pilih triple time estimate dengan network type start/end node number

b. Masukkan jumlah number of task berdasarkan banyaknya jalur kegiatan kerja

c. Input sesuai dengan data yang ada, mulai dari task (kegiatan), start node (awal kegiatan), end node (akhir kegiatan), optimistic time (waktu optimis), most likely time (waktu realistis) sampai pessimistic time (waktu pesimis)

d. Kemudian solve

\begin{tabular}{||l|r|r|r|r|r|}
\hline \hline \multicolumn{5}{|c|}{ Proyek IPAL } \\
\hline & Start node & End node & $\begin{array}{r}\text { Optimistic } \\
\text { time }\end{array}$ & $\begin{array}{r}\text { Most Likely } \\
\text { time }\end{array}$ & $\begin{array}{r}\text { Pessimistic } \\
\text { time }\end{array}$ \\
\hline Task 1 & 1 & 2 & 12 & 14 & 17 \\
\hline Task 2 & 2 & 3 & 13 & 17 & 20 \\
\hline Task 3 & 2 & 4 & 12 & 15 & 18 \\
\hline Task 4 & 3 & 5 & 28 & 30 & 35 \\
\hline Task 5 & 3 & 6 & 9 & 4 & 6 \\
\hline Task 6 & 4 & 7 & 1 & 2 & 3 \\
\hline Task7 & 5 & 8 & 5 & 9 & 13 \\
\hline Task 8 & 6 & 8 & 5 & 9 & 13 \\
\hline Task 9 & 6 & 9 & 4 & 7 & 8 \\
\hline Task 10 & 7 & 9 & 4 & 7 & 8 \\
\hline Task 11 & 8 & 10 & 8 & 12 & 15 \\
\hline Task 12 & 9 & 10 & 8 & 12 & 15 \\
\hline Task 13 & 10 & 11 & 3 & 5 & 7 \\
\hline Task 14 & 11 & 12 & 1 & 3 & 5 \\
\hline \hline
\end{tabular}

Gambar 3: PERT pada software POM-QM

Hasil dari penyelesaian program tersebut di dapat diagram jaringan kerja dan tabel waktu sebagai berikut :

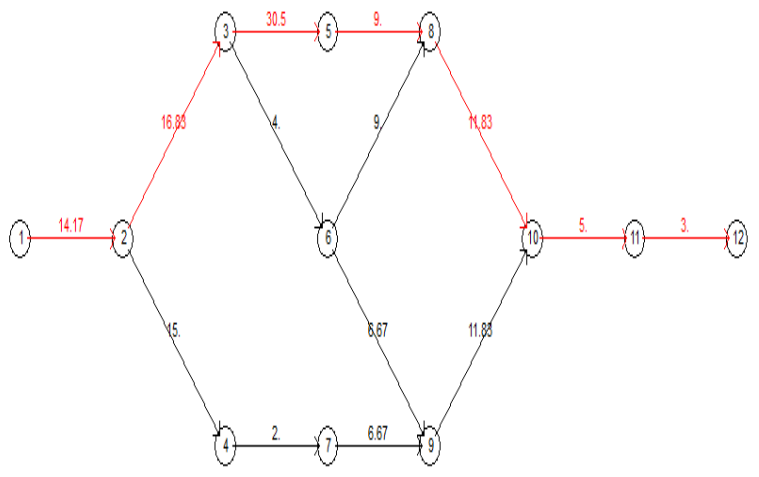

Gambar 4: PERT pada software POM-QM

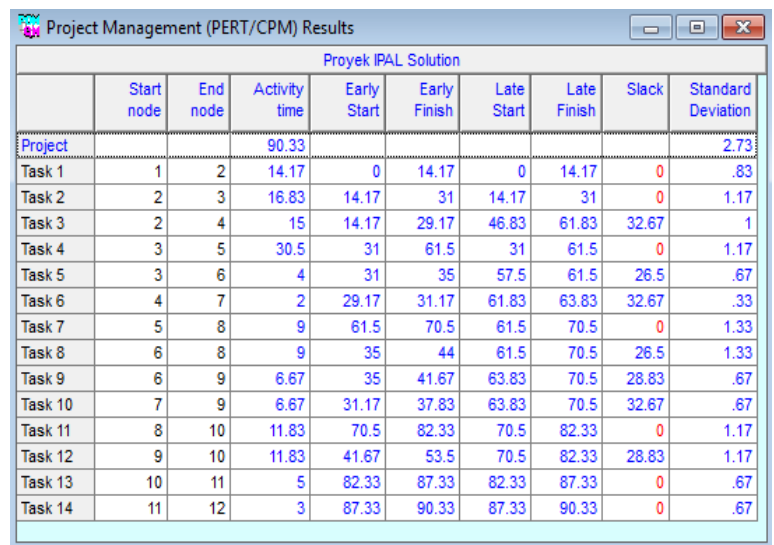

Gambar 5: Hasil penyelesaian menggunakan software POM-QM

Dari diagram jaringan kerja dapat diketahui jalur kritisnya (yang bernilai slack $=0$ ) yaitu dimulai dari A-B-C-E-H-J-K-L. dengan waktu penyelesainnya adalah 90.33 hari atau 91 hari. 


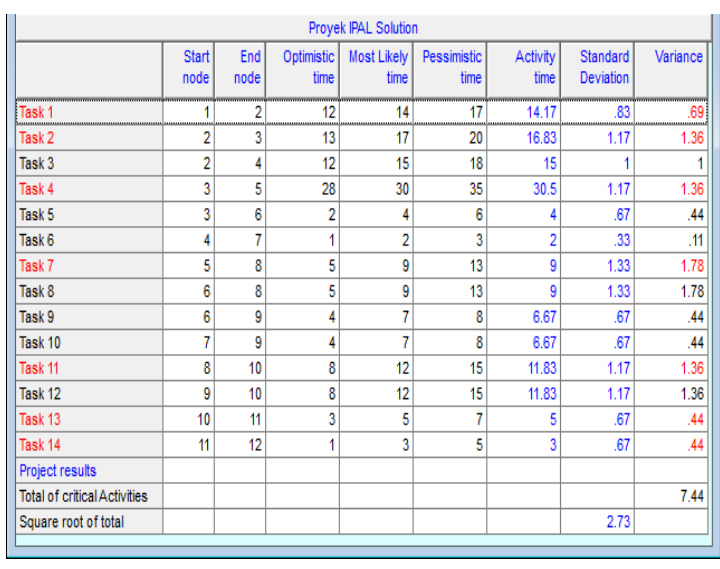

Gambar 6: Standar deviasi dan variance tiap kegiatan kerja

Dari gambar diatas diketahui besarnya standar deviasi untuk keseluruhan proyek adalah 2.73 dan variansnya adalah 7.44. dari nilai tersebut kemudian dicari kemungkinan atau probabilitas waktu penyelesaian perkerjaan proyek dalam 90.33 hari bedasarkan distribusi normal.

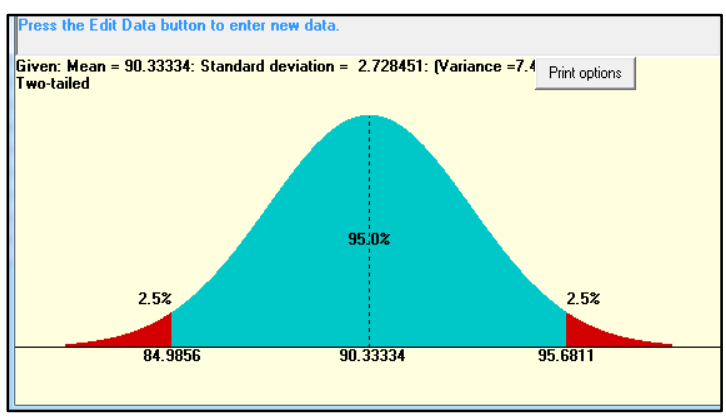

Tabel 4: Hasil percepatan waktu proyek dan biaya percepatannya.

\begin{tabular}{|c|c|c|c|c|c|c|}
\hline \multirow{2}{*}{ No. } & \multirow{2}{*}{ Kegiatan } & \multicolumn{2}{|c|}{ Waktu (hari) } & \multicolumn{2}{|c|}{ Biaya per hari (Rp) } & \multirow{2}{*}{$\begin{array}{c}\text { Biaya percepatan per } \\
\text { hari (Rp) }\end{array}$} \\
\hline & & Normal & Cepat & Normal & Cepat & \\
\hline A. & Persiapan & 0 & 0 & 0 & 0 & 0 \\
\hline B. & Pondasi bangunan & 14.17 & 13 & $7,000,000$ & $7,500,000$ & 250,000 \\
\hline C. & $\begin{array}{l}\text { Pembuatan kerangka } \\
\text { konstruksi }\end{array}$ & 16.83 & 14 & $5,000,000$ & $5,900,000$ & 300,000 \\
\hline D. & Pemasangan atap & 15 & 15 & $4,000,000$ & $4,000,000$ & 0 \\
\hline E. & Perakitan mesin belt press & 30.50 & 30 & $650,000,000$ & $650,400,000$ & 400,000 \\
\hline $\mathrm{F}$. & $\begin{array}{l}\text { Pelevelan media mesin belt } \\
\text { press }\end{array}$ & 4 & 4 & 800,000 & 800,000 & 0 \\
\hline G. & Instalasi penerangan & 2 & 2 & $1,000,000$ & $1,000,000$ & 0 \\
\hline $\mathrm{H}$. & $\begin{array}{l}\text { Pemasangan pompa dan } \\
\text { compressor }\end{array}$ & 9 & 6 & $25,000,000$ & $25,600,000$ & 200,000 \\
\hline $\mathrm{I}$. & $\begin{array}{l}\text { Pemasangan bak } \\
\text { penampung sludge }\end{array}$ & 6.67 & 6.67 & $6,000,000$ & $6,000,000$ & 0 \\
\hline $\mathrm{J}$. & $\begin{array}{l}\text { Perakitan kontrol panel } \\
\text { mesin belt press }\end{array}$ & 11.83 & 10 & $15,000,000$ & $15,800,000$ & 400,000 \\
\hline $\mathrm{K}$. & $\begin{array}{l}\text { Pemasangan kontrol panel } \\
\text { mesin belt press }\end{array}$ & 5 & 3 & $3,000,000$ & $3,500,000$ & 250,000 \\
\hline L. & $\begin{array}{l}\text { Trial pengoperasian mesin } \\
\text { belt press }\end{array}$ & 3 & 2 & 800,000 & $1,100,000$ & 300,000 \\
\hline & TOTAL & & & $717,600,000$ & $721,400,000$ & $2,100,000$ \\
\hline
\end{tabular}


Dalam menentukan kegiatan yang akan di crash terlebih dilakukan perhitungan biaya percepatan per hari (cost slope) sesuai persaman [3.5], dari semua kegiatan pada jalur kritis. Kemudian dipilih kegiatan yang mempunyai biaya percepatan per hari terkecil. Dari tabel 4 dapat diketahui yakni kegiatan $\mathrm{H}$ (pemasangan pompa dan kompressor) sebesar Rp. 200,000,per hari. Untuk proyek ini akan dilakukan crashing waktu 1 hari dan 3 hari. Dari hasil perhitungan diperoleh nilai cost slope untuk masing - masing percepatan hari kerja seperti tabel di bawah ini :

Tabel 5. Hasil perhitungan crashing 1 hari dan 3

\begin{tabular}{|c|l|c|c|c|c|}
\hline No & Keterangan & $\begin{array}{c}\text { Waktu } \\
\text { pen } \\
\text { yelesaian } \\
\text { (hari) }\end{array}$ & $\begin{array}{c}\text { Waktu } \\
\text { yang } \\
\text { dipercepat } \\
\text { (hari) }\end{array}$ & $\begin{array}{c}\text { Biaya } \\
\text { proyek } \\
\text { (Rp) }\end{array}$ & $\begin{array}{c}\text { Biaya } \\
\text { tambahan } \\
\text { (Rp) }\end{array}$ \\
\hline 1 & $\begin{array}{l}\text { Waktu } \\
\text { normal }\end{array}$ & 91 & 0 & $\begin{array}{c}717,6 \\
00,00 \\
0\end{array}$ & 0 \\
\hline 2 & $\begin{array}{c}\text { Percepat } \\
\text { an 1 hari }\end{array}$ & 90 & 1 & $\begin{array}{c}717,8 \\
00,00 \\
0\end{array}$ & 200,000 \\
\hline 3 & $\begin{array}{c}\text { Percepat } \\
\text { an 3 hari }\end{array}$ & 88 & 3 & $\begin{array}{c}718,2 \\
00,00 \\
0\end{array}$ & 600,000 \\
\hline
\end{tabular}

\section{KESIMPULAN}

Berdasarkan penelitian yang telah dilakukan terhadap proyek pengolahan limbah PT. Kino Indonesia Tbk. maka dapat disimpulkan bahwa :

1. Dengan menggunakan metode PERT proyek pengolahan limbah PT. Kino Indonesia Tbk. dapat selesai dalam jangka waktu 91 hari dan lintasan kritis terletak pada kegiatan A-B-CE-H-J-K-L dengan kemungkinan selesai paling cepat 85 hari adalah $2.5 \%$, paling mungkin diselesaikan 91 hari adalah $95 \%$ dan paling lambat 96 hari adalah $2.5 \%$

2. Dengan alternative penambahan waktu 1 hari dan 3 hari maka proyek dapat diselesaikan dalam 90 hari dengan penambahan biaya sebesar Rp. 200,000,- dan dalam 88 hari dengan penambahan biaya Rp. 600.000,-, dengan besar cost slope Rp. 200.000 per hari.

\section{REFESENSI}

Badri. Sofwan 1997. Dasar-dasar Network Planning. Jakarta: PT. Rineka Cipta.

Misrali, Eka Bambang G, Ariwan Joko N. 2015. Evaluasi Penjadwalan Waktu dan Biaya Pada Proyek Pembangunan Gedung Kelas di Fakultas Ekonomi Universitas Jember Dengan Metode PERT. Artikel Ilmiah Mahasiswa. Jember: Universitas Jember.

Fadli, M., Syarif SS. 2010. Model Teori Manajemen Proyek. Politeknik Caltex Riau.

Schwalbe, K., 2007. Informaton Technology Project Management. Thomson Course Technology. edisi 5.

Ridho, Muhammad Rizki, Syahrizal. 2015. Evaluasi Penjadwalan Waktu dan Biaya Proyek Dengan Metode PERT dan CPM. Jurnal Ilmiah. Universitas Sumatera Utara. 